\title{
FIRST-HAND LEARNING PARTICIPATION: AN EMPIRICAL ANALYSIS OF THE LEARNING OUTCOMES OF LONG TERM STAY MALAYSIAN STUDENTS IN JAPAN
}

\author{
Rahimah Muhammad Nor, Asmadi Hassan and Rohayati Paidi
}

\begin{abstract}
Studying in a foreign country is one of the ways to enhance students' competencies in facing challenges of global competitiveness and in being marketable for future career choices. This research investigates the impact of cross-cultural adaptation among Malaysian students $(N=245)$ who enrolled in various universities in Japan. Quantitative method was used to examine changes in the following five factors: personal changes, cross-cultural awareness, cross-cultural interaction, global mindedness and intellectual development. The findings demonstrate that studying abroad brings positive outcomes in students' personal development. Hence, student mobility is an invaluable experience and administrators should support and encourage young people to explore "real life" globally.
\end{abstract}

Keywords: personal changes, cross-cultural awareness, cross-cultural interactions, global mindedness, intellectual development, socio-cultural adaptation

\section{Introduction}

Culture is defined as "all that human beings learn to do, to use, to produce, to know, and to believe as they grow to maturity and live out their lives in the social groups to which they belong." Culture is normally learned through social learning processes in a group or shared experiences which is directly transmitted from generation to generation and this affects behaviour, thinking and feeling towards people in different social environments.

Today, international mobility has become significant through increasing activities across national boundaries such as traveling, the promotion of international businesses and investments, global migration, and international education. Globalization intensifies social relations across time and space. ${ }^{2}$ Therefore, the interconnected global world has influenced the changing marketplace where employees seek individuals with a global perspective on cross-cultural competence and flexibility. To be successful in the $21^{\text {st }}$ century, young people must acquire the skills that allows them to compete globally. As Anderson remarks,

International travel has become more commonplace and as the economics of the world have become more interdependent, both students and faculties are recognizing the need to prepare for this new, shrinking world. ${ }^{3}$

\footnotetext{
${ }^{1}$ Henry L. Tischler, Introduction to Sociology, Belmont, CA: Cengage Learning, 2010.

${ }^{2}$ Manfred Steger, Globalization, New York: Sterling Publishing Company, Inc., 2010, p 15.

${ }^{3}$ Linda E. Anderson, "A New Look at an Old Construct: Cross-cultural Adaptation," International Journal of Intercultural Relations, Vol. 18, No. 3, 1994, p 458.
} 
Studying abroad provides young people with first-hand learning opportunities to engage internationally. It is an as an effective way to receive real-life and practical learning in the face of challenges of globalisation. Students as "young travellers" have a variety of perceptions and interpretations about their foreign experiences. Hence, this study provides a comprehensive analysis of a deeper understanding about student learning and development.

\section{Literature Review}

Numerous studies have been conducted to assess the impact of cross-cultural involvement of students. Some research focuses on intercultural sensitivity. ${ }^{4}$ For example, Straffon conducted intercultural sensitivity research among high school students attending an international school. 326 students from United States of America, Korea, Japan, Malaysia and Australia participated in the study. The findings showed that 71\% (238) of the students were at the acceptance stage and $26 \%$ (88) were at the adaptation stage. Analysis indicated that the minimum score of the level of intercultural sensitivity was at 3.28 while maximum stage of adaptation was between 4.50 and $5.49 .^{5}$

In addition, Bayles conducted another intercultural sensitivity research among 233 elementary school teachers who worked in five bilingual schools in an urban Texas school district. The result indicated that these teachers' intercultural sensitivity was at 95.09 (minimization stage in Bennett's DMIS). The level of intercultural sensitivity found a significant difference through two independent variables: years of experience teaching in schools $[F(2,230)$ $=3.78, p<.05]$ and years teaching ethnically diverse students $[F(2,230)=4.82, p<.05] .^{6}$

4 Philip H. Anderson, Leigh Lawton, Richard J. Rexeisen, Ann C. Hubbard, "Short-term study abroad and intercultural sensitivity: A pilot study," International Journal of Intercultural Relations, Vol. 30, No. 4, 2006, pp 457-469; Patricia Anne Armfield, “An examination of the relationship between students' interaction with host nationals while on study abroad and their development of intercultural sensitivity" (PhD Thesis, University of Maryland, 2004); Peggy Porterfield Bayles, "Assessing the intercultural sensitivity of elementary teachers in bilingual schools in a Texas school district” (PhD Thesis, University of Minnesota, 2009); Milton J. Bennet, “A developmental approach to training for intercultural sensitivity," International journal of intercultural relations, Vol. 10, No. 2, 1986, pp 179-196; Dharm Bhawuk, Richard Brislin, "The measurement of intercultural sensitivity using the concepts of individualism and collectivism," International Journal of Intercultural Relations, Vol. 16, No. 4, 1992, pp 413-436; Guo-Ming Chen, William J. Starosta, "Intercultural communication competence: A synthesis," Communication yearbook, Vol. 19, 1996, pp 353-384; Lilli Engle, John Engle, “Assessing Language Acquisition and Intercultural Sensitivity Development in Relation to Study Abroad Program Design," Frontiers: The Interdisciplinary Journal of Study Abroad, Vol. 10, 2004, pp 219-236; Thomas L. Fuller, "Study abroad experiences and intercultural sensitivity among graduate theological students: A preliminary and exploratory investigation," Christian higher education, Vol. 6, No. 4, 2007, pp 321-332; Jane Jackson, "Globalization, internationalization, and short-term stays abroad," International Journal of Intercultural Relations, Vol. 32, No.4, 2008, pp 349-358; Adriana Medina-Lopez-Portillo, "Intercultural Learning Assessment: The Link between Program Duration and the Development of Intercultural Sensitivity," Frontiers: The Interdisciplinary Journal of Study Abroad, Vol. 10, 2004, pp 179-199; David A. Straffon, "Assessing the intercultural sensitivity of high school students attending an international school," International Journal of Intercultural Relations, Vol. 27, No. 4, 2003, pp 487-501.

${ }^{5}$ David A. Straffon, "Assessing the intercultural sensitivity of high school students attending an international school," International Journal of Intercultural Relations, Vol. 27, No. 4, 2003, pp 487-501.

${ }^{6}$ Peggy Porterfield Bayles, "Assessing the intercultural sensitivity of elementary teachers in bilingual schools in a Texas school district” (PhD Thesis, University of Minnesota, 2009). 
Apart from that, studies were also conducted in an attempt to identify the cross-cultural adaptation stages in operating successfully in a global environment. For example, Winkelman proposes four stages of the adaptation process which consist of the tourist phase, culture shock, adjustment and acculturation. Similarly, the Berkeley International Office identified four stage of cultural adjustment consisting of the honeymoon period, crisis mode, recovery time and adjustment period. Adaptation refers to the process where individuals, upon relocating to a foreign cultural environment, try to maintain a functional relationship within the new environment. ${ }^{7}$

Furthermore, Van der Zee and Van Oudenhoven suggests five dimensions of intercultural adjustment of expatriates-cultural empathy, open-mindedness, social initiative, emotional stability, and flexibility. ${ }^{8}$ On the other hand, Ward and Kennedy state psychological adjustment consist of homesickness, external locus of control, life changes, and social difficulty and sociocultural adaptation consist of cultural distance, language ability, and satisfaction with host national contact, cultural separation and mood disturbance. ${ }^{9}$ In most cases, success in dealing with intercultural challenges depends on situations, motives, reasons, and commitment toward new environment. ${ }^{10}$ Matsumoto and other researchers found that psychological components consist of emotion regulation, openness, personal autonomy, flexibility and creativity that are related to intercultural adjustment. ${ }^{11}$ In terms of culture shock, there are individuals who go abroad but are unable to adjust to a new cultural environment which affects one's cognitive overload and behavioural inadequacy to responding to a new environment. ${ }^{12}$ Meanwhile, many other reseachers have focused on the impact on one's global perspectives. ${ }^{13}$ The Center for Global and Intercultural Study identified global perspective as how individuals can emphatize with another person's perspective, seek interactions with people different from oneself, have an

\footnotetext{
${ }^{7}$ Kim Young Yun, “Adapting to an unfamiliar culture: An interdisclipinary overview” in Handbook of International and Intercultural Communication 2nd ead., ed. Gudykunst, W.B., and B. Mody (Thousand Oaks: Sage Publications), p 260.

${ }^{8}$ Van der Zee and Van Oudenhoven, "The Multicultural Personality Questionnaire: A multidimensional instrument of multicultural effectiveness," European Juournal of Personality, Vol. 14, No. 4, 2000.

${ }^{9}$ Colleen Ward, Antony Kennedy, "Psychological and socio-cultural adjustment during cross-cultural transitions: A comparison of secondary students overseas and at home," International Journal of Psychology, Vol. 28, No. 2, 1993, pp 129-147; Colleen Ward, Antony Kennedy, "Acculturation strategies, psychological adjustment, and sociocultural competence during cross-cultural transitions," International Journal of Intercultural Relations, Vol. 18, No. 3, 1994, pp 329-343.

${ }^{10}$ Kim Young Yun, Becoming intercultural: An integrative theory of communication and cross-cultural adaptation, Thousand Oaks: Sage Publications, 2000.

${ }^{11}$ Matsumoto et al., "Development and validation of a measure of intercultural adjustment potential in Japanese sojourners: The Intercultural Adjustment Potential Scale (ICAPS)," International Journal of Intercultural Relations, Vol. 25, No. 5, 2001.

12 . Henry L. Tischler, Introduction to Sociology, Belmont, CA: Cengage Learning, 2010; Michael Winkelman, "Cultural shock and adaptation," Journal of Counseling \& Development, Vol. 73, No. 2, 1994, pp 356-371.

${ }^{13}$ Lester Thomas McCabe, "The development of a global perspective during participation in semester at sea: A comparative global education program," Educational Review, Vol. 46, No. 3, 1994, pp 275-286; Kelly Carter Merrill, David C. Braskamp, Larry A. Braskamp, “Assessing Individuals' Global Perspective," Journal of College Student Development, Vol. 53, No. 2, 2012, pp 356-360; Patricia A. Golay, "The effects of study abroad on the development of global-mindedness among students enrolled in international programs at Florida State University" (PhD Thesis, The Florida State University, 2006); Kevin Kehl, Jason Morris, "Differences in global-mindedness between short-term and semester-long study abroad participants at selected private universities," Frontiers: The Interdisciplinary Journal of Study Abroad, Vol. 15, 2007, pp 67-79; Donald L. Sampson, Howard P. Smith, “A scale to measure world-minded attitudes,” The Journal of Social Psychology, Vol. 45, No. 1, 1957, pp 99-106.
} 
awareness of one's impact on others within various cultural contexts especially cross cultural differences and on global issues.

Conversely, global-mindedness is defined as "a worldview in which one sees oneself as connected to the world community and feel a sense of responsibility for its members. This commitment is reflected in an individual's attitudes, beliefs and behaviours. ${ }^{14} \mathrm{~A}$ highly global minded individual will have a "strong sense of appreciation of diversity and differences, and an awareness and appreciation for the interconnectedness of the world." 15 In addition, some studies also have examined the impact of mobility abroad in terms of global competency. ${ }^{16}$ According to Hunter, global competence means "having an open mind while actively seeking to understand cultural norm and expectations of others, leveraging this gained knowledge to interact, communicate and work effectively outside of one's own environment."17

Interrelationships between variables are invaluable in order to understand the potential significant relation between impacts of study abroad programme. Hence, the purpose of this research is to measure inter-correlation between learning outcomes among Malaysian students participating in studying abroad programs in various universities located in Japan. Compared to previous studies, this study adds new insights to long term staying Malaysian students studying in Japan.

\section{Methodology}

Samples used in this survey were Malaysian students pursuing their studies in various universities in Japan. The researchers used both qualitative and quantitative methods to examine the level of learning outcomes as goals of study abroad. This research study chose to use online survey as data collection method. The ordinal scale was used as a measurement tool, consisting of $1=$ not at all, $2=$ very little, $3=$ sometimes, $4=$ quite a bit and $5=$ very much.

Descriptive statistics were used to describe the sample demographic and level of learning outcomes by respondents. Meanwhile, the Spearman Rho as inferential statistics were also used to examine the results obtained pertaining to the research question. The Spearman Rho tests were conducted to comprehensively measure correlation between learning outcomes by students who study abroad. This study was designed to address the following research questions:

RQ1: To what extent is the level of significant correlation between learning outcomes? RQ2: What adjustments were made to adapt into a new environment in Japan?

14 "The development of an instrument to measure global-mindedness" (PhD Thesis, University of San Diego, 1993), quoted in Patricia A. Golay, "The effects of study abroad on the development of global-mindedness among students enrolled in international programs at Florida State University" (PhD Thesis, The Florida State University, 2006 ), p 8.

${ }^{15}$ Rebecca A. Hansen, "Impact of study abroad on ethnoultural empathy and global-mindedness" (PhD Thesis, Ball State University, 2010), p 7.

${ }^{16}$ Susan W. Herrera, "Effectiveness of study abroad in developing global competence and global consciousness: Essential outcomes for internationalizing the curriculum" (PhD Thesis, University of Florida, 2008); William D. Hunter, "Knowledge, skills, attitudes, and experiences necessary to become globally competent" (PhD Thesis, Lehigh University, 2004); Christa Iee Olson, Kent R. Kroeger, "Global competency and intercultural sensitivity," Journal of Studies in International Education, Vol. 5, No. 2, 2001, pp 116-137; Jack R. Lohmann, Howard A. Rollins, J. Joseph Howey, "Defining, developing and assessing global competence in engineers," European Journal of Engineering Education, Vol. 31, No. 1, 2006, pp 159-183.

${ }_{17}$ William D. Hunter, "Knowledge, skills, attitudes, and experiences necessary to become globally competent" (PhD Thesis, Lehigh University, 2004), p 101. 


\section{Profile of Respondents}

A total number of 245 Malaysian students participated in this study, consisting 149 (60.8\%) males and $96(39.2 \%)$ females $(M=1.39, S D=.48)$. In terms of location, students were divided according to regions in Japan based on the location of their university - Kinki 33 (14\%), Chubu 46 (19\%), Kanto 87 (35\%), Tohoku 32 (13\%), Kyushu 10 (4\%), Chugoku 25 (10\%), Hokkaido 8 $(3 \%)$ and Shikoku $4(2 \%)(M=3.2735, S D=1.67513)$.

\section{The Results}

\section{Personal Changes}

The hardship of living in a foreign country allows students to develop positive changes in terms of learning and development. Students who enrolled for a full academic year abroad acquired deeper independence, self-confidence, tolerance of others, and intense interpersonal relational skills. Respondents mentioned open mindedness as the most important outcome of the study abroad programme. When questioned about the level of open mindedness, a total of 163 of respondents expressed "very much" and 58 "quite a bit" (mean value of 4.56 and standard deviation of .68).

In addition, the majority of respondents responded that the participation contributed to their tolerant attitude towards people of different cultural background. A total of 164 respondents said "very much" and 53 remarked "quite a bit" in terms of tolerating foreign cultural background (Likert-type scale - mean value of 4.55 and standard deviation of .71). Meanwhile, the respondents believed that living in an unfamiliar social environment influenced their selfreliance with significant number of 130 respondents answering "very much" and 82 individuals remarking "quite a bit" (mean value of 4.39 and standard deviation of .73). The data analysis also highlighted that a total of 130 respondents answered "very much" and 67 are "quite a bit", based on a Likert-type scale when asked about curiosity in regards to other cultures (mean value of 4.30 and standard deviation of .87).

\section{Cross-cultural Awareness}

Literature shows that the decision to study abroad likely helps the participants to overcome their comfort zone and explore different social lifestyle and values that can lead to intercultural competence. Therefore, studying abroad is an effective way to help students develop their crossculture adaptability, understanding about other cultures, self-cultural awareness, and increase respect and positive attitude toward others.

In terms of cross-cultural awareness, descriptive statistical analysis showed that an overwhelming majority of respondents mentioned study abroad in Japan influenced their awareness about diversity of cultures with a total of 213 respondents strongly agreeing with this statement (mean value of 4.80 and standard deviation of .53). Respondents who enrolled a full year academic study abroad are more likely to have greater exposure and understanding about foreign culture and way of life. 
Meanwhile, analysis indicated significantly higher mean value of 4.71 with standard deviation of .55 , which most respondents remarked study abroad participation increased their respect towards people with different values and customs. A total of 186 respondents answered "very much" and 47 "quite a bit" for this question. The result also found a total of 177 respondents strongly agreeing as "very much" where interacting with culturally-distinct person influenced their higher level of appreciation of cultural differences (mean value of 4.66 and standard deviation of .60). Furthermore, data analysis reported a significant outcome revealing that living abroad enhanced students' ability to accept people from different cultures with a total of 145 respondents saying "very much" and 78 "quite a bit", in the Likert-type scale (mean value of 4.50 and standard deviation of .66).

\section{Cross-cultural Interaction}

The majority of respondents agreed with the statement that study abroad programmes influenced their willingness to work together with different people. A total of 163 respondents responded "very much" and 64 "quite a bit" based on the Likert-type scale (mean of 4.59 and standard deviation of .64). The result also showed respondents reported significant outcomes with the statement that study abroad programme enhanced their ability to accept different perspectives or views from other people. A total of 134 respondents chose "very much" and 79 "quite a bit" on the Likert-type scale (mean value of 4.42 and standard deviation .71). In addition, respondents mentioned that learning and participation of diversity in environment influenced their interest and exchange ideas with others. A total of 133 respondents strongly agreed with chose "very much" and 59 "quite a bit" for this statement (mean value of 4.29 and standard deviation of .89).

Lastly, through foreign interaction, students might enhance their ability to share or express their own perspective with people of a different culture. A total of 78 respondents answered "very much" and 101 "quite a bit" for this statement (mean value of 4.02 and standard deviation of .82). In global competition, studying abroad programmes provide youths with opportunity to engage in social interactions with international society and potentially increases their openness to a variety of perspectives.

\section{Global-mindedness}

Statistical analysis indicated that study abroad participation had a positive impact on several variables. The result revealed that the majority of respondents strongly agreed that study abroad programme significantly influenced their awareness about the importance of Malaysia-Japan relations. For this outcome, 157 respondents answered "very much" and 56 "quite a bit" based on the Likert-type scale (mean value of 4.49 and standard deviation of .77). Data from the survey also indicated participants assessed that study abroad program enhanced their alertness to global issues. To this, a total of 85 respondents answered "very much" and 82 "quite a bit" based on the Likert-type scale (mean value of 3.96 and standard deviation of .93).

Meanwhile, a total of 83 respondents that answered "very much" strongly felt that study abroad participation developed global citizenships (mean value of 3.89 and standard deviation of 1.01). Respondents also mentioned that there were significant changes in their ability to evaluate global problems in different cultures, where 63 respondents scored "very much" and 75 "quite a bit" for this statement (mean value of 3.68 and standard deviation of 1.02). 


\section{Intellectual Development}

In term of intellectual development, the majority of respondents remarked that study abroad in Japan contributed to improvement of their host language with a total of 110 respondents answered "very much" and 93 "quite a bit" with this statement (mean value of 4.25 and standard deviation of .80). Respondents stated that foreign language proficiency is important to establish relationship with host peer and understanding learning process in classes. The data of survey also reported that there was positive impact on understanding about their own strength and weaknesses. For this, a total of 116 respondents expressed "very much" and 84 "quite a bit" on the Likert-type scale (mean value of 4.25) and standard deviation of 85).

Furthermore, respondents mentioned that study abroad programme influenced their desire to engage in international organisations for future employment. This statement was agreed by 125 of respondents that answered "very much" and 68 "quite a bit" (mean value of 4.21 and standard deviation of 1.00). The result indicated that study abroad participants have higher level of understanding of their own abilities, interests and personalities. A total of 82 respondents answered "very much" and 100 "quite a bit" for this statement (mean value of 4.02 and standard deviation of .87).

\section{The Findings}

RQ1: To what extent is the level of significant correlation between learning outcomes?

The first research question examines what was the interrelationship among learning outcomes. Figure 1 indicated inter-correlation between variables. The finding found that the Spearman Rho coefficients for the relationship between personal growth and cross-cultural awareness is $r=.743$, $p<.01$ and it is strong correlation. In addition, a significant correlation was found between personal goals and cross-cultural interaction $(r=.645, p<.01)$, global-mindedness $(r=.533, p$ $<.01)$ and intellectual development $(r=.563, p<.01)$. There is a moderate correlation. Meanwhile, cross-cultural awareness was found to correlate strongly with cross-cultural interaction $(r=.736, p<.01)$ and this is relatively a strong correlation.

Furthermore, a positive significant was found between cross-cultural awareness and global-mindedness $(r=.600, p<.01)$ and intellectual development $(r=.617, p<.01)$. There is a positive and moderate correlation. The global-mindedness is of moderate correlation with crosscultural interaction $(r=.653, \mathrm{p}<.01)$ and intellectual development $(r=.598, \mathrm{p}<.01)$. Lastly, Spearman Rho coefficients showed that there is positive correlation between intellectual development with cross-cultural interaction $(r=.590, \mathrm{p}<.01)$ (See Figure 1$)$.

The finding revealed that there was significant and strong correlation between crosscultural awareness, personal changes and cross-cultural interaction. The statistical analysis indicated that cross-cultural awareness and personal changes $(r=.743, p<.01)$ and crosscultural interaction $(r=.736, p<.01)$. Specifically, personal changes directly developed intercultural skills through participating actively in foreign interactions. This finding might suggest that encounter with an unfamiliar environment and immersion with different culture is a useful tool that increases students' open-mindedness, flexibility, tolerance, self-confidence, and 
independence. These valuable outcomes often are associated with positive attitudes towards an increase in intercultural skills.

Figure 1: Inter-correlation between scales

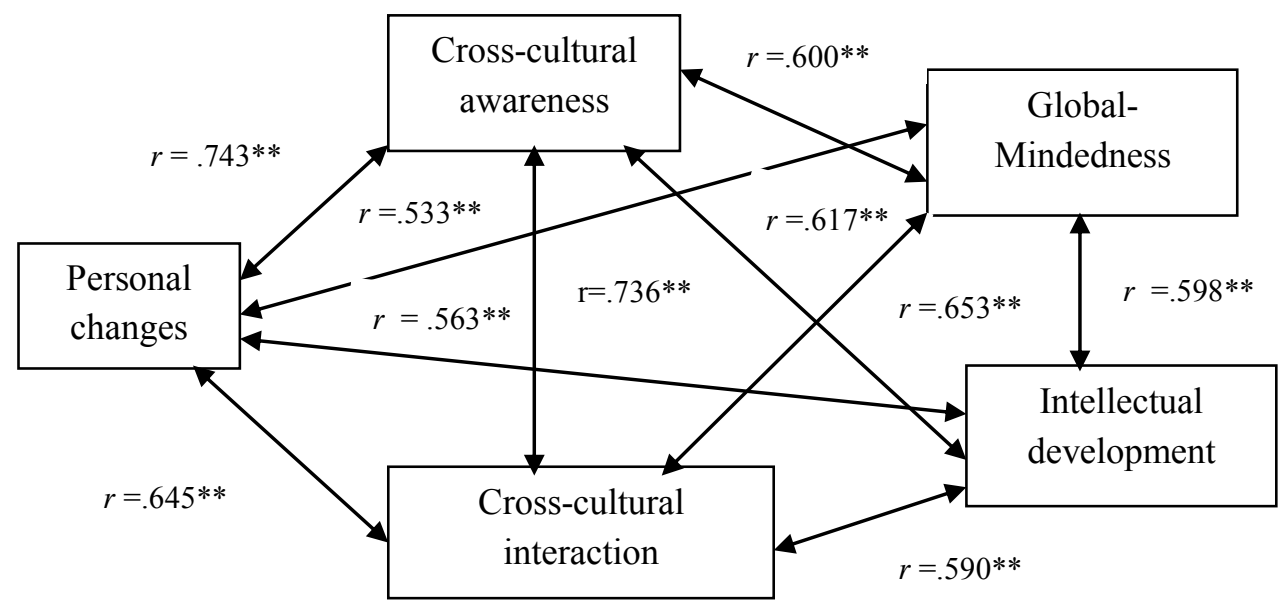

Author's observation **. Correlation is significant at the 0.01 level (2-tailed)

The Spearman Rho analysis also indicated that there was strong correlation between cross-cultural awareness and cross-cultural interactions $(r=.736, p<.01)$. Through interaction, students might build intercultural friendship and influence their understanding, respect, and appreciation of other cultures. This is supported by Wortman's (2002) research that concluded students who fully integrate into the host culture during their study abroad influenced their openness towards diversity. Meanwhile Yu (2008) suggested that foreign language ability and understanding about host culture contributes to closer relationship with host peoples.

Next, personal changes correlates with cross-cultural interaction $(r=.645, \mathrm{p}<.01)$, intellectual development $(r=.563, \mathrm{p}<.01)$ and global-mindedness $(\mathrm{r}=.533, \mathrm{p}<.01)$. The finding explained that respondents had positive personal changes associated with the ability to get along with other people. The respondents also more likely gained higher level of open-mindedness; developed a sense of tolerance and deeper self-confidence when interacting with different peoples and perspectives. From these changes, respondents might be more comfortable and enjoy collaboration and teamwork with foreigners.

The personal changes positively correlated with intellectual development $(r=.563, \mathrm{p}$ $<.01)$ demonstrated that challenges of living and adapting to new surroundings might increase problem-solving skills, become more independent in life management and more flexible towards new environment. Meanwhile, positive correlation between personal changes and globalmindedness $(r=.533, \mathrm{p}<.01)$ showed that positive attitude when dealing with different perspectives directly related to a greater sense of global-mindedness. The result suggested that openness toward different perspectives and willingness to accept other peoples' opinions significantly affected students' way of thinking about the world. 
The finding reveals that global-mindedness is positive and is significantly related with cross-cultural interactions $(r=.653, \mathrm{p}<.01)$ and intellectual development $(r=.598, p<.01)$. Fullyear academic study programmes in foreign countries leads to knowledge gain about new ideas and concepts and provides students more opportunity to work together or cooperate with different type of people. Social interactions with colleagues through discussions and learning processes in classes exposes students to different perspectives and expands their global perspective. The study conducted by Zhai and Scheer (2004) found that students who had more contacts with people from other countries increased their level of global perspective significantly.

Besides that, the analysis also indicated there was positively significant correlation between global-mindedness and intellectual development $(r=.598, p<.01)$. The finding described that study abroad participation influenced students' cross-cultural communication skills to function effectively and successfully when interacting between cultures in global context.

Meanwhile, cross-cultural awareness indicated positive and significant correlation between global-mindedness $(r=.600, \mathrm{p}<.01)$ and intellectual development $(r=.617, \mathrm{p}<.01)$. The finding explained that awareness about differences in culture reflected openness toward various dimensions of global issues which affected students' international knowledge and understanding. The statistical analysis indicated that global engagement also influenced their awareness about importance of diplomatic relations between Malaysia and Japan. Clearly, students engaged in diversity of environment are more likely to expand their horizons.

The correlation between cross-cultural awareness and intellectual development $(r=.617$, $\mathrm{p}<.01)$ explains that in challenges to make adjustment in different culture and social environments, respondents are more likely to understand their abilities in terms of problemsolving and critical. Besides that, respondents believe that understanding other cultures and speaking foreign languages directly influenced their desire to engage in international employment.

\section{Socio-cultural adaptation in Japan}

\section{RQ2: What adjustments were made to adapt into a new environment in Japan?}

After coding the wide range of answers, it was clear that few aspects of adjustment cover interaction and communication, time management, Japanese culture, social environment, personal changes, and financial management were crucial. The finding revealed that of those who responded $(\mathrm{N}=236)$, about $39 \%$ remarked that interaction and communication aspects were most important adjustment issues when dealing with a different culture and environment in Japan. Some students realised that participating in university club or any activities with Japanese students provided extra opportunities to interact with the Japanese as well as improve their communication skills in the local language.

Respondents believed that frequency of interactions with Japanese students enhanced their understanding about the attitude and culture of the people. To successfully adapt to an unfamiliar environment, individuals need to actively learn and participate and this is supported by Dwyer (2004) who notes that interaction with national hosts increased understanding about host culture and language. Some respondents commented that, 
I realise that I need to learn to inculcate more informal verse or slang in order to communicate with them. Before this I was more comfortable using the language most commonly used in formal situations, but to make friends with people who are of the same age group, I realised it is important to adapt to their way of speaking. (Male student from Nagoya University)

I adapt to new environments by using the Japanese language that was learned prior to coming to Japan. Attempt to better communicate and share views about my own country with them. (Male student from Osaka University)

I adapt through interaction with Japanese friends and try to understand the attitude of Japanese people. (Male student from Gifu University)

I work hard to speak Japanese well I think my Japanese language is still not very good but, at least now I can speak with them normally in everyday life. Increasing the number of friends is also my way to adjust my lifestyle in Japan. (Male student from Yokohama National University)

I've made some friends and learnt the region's slang and accent along the way. (Female student from Nagoya University)

I joined the club at the university to get more opportunities to interact with Japanese people. (Male student from Osaka University)

My subject are all in Japanese, sometimes there's a difficulty to get a real understanding of the knowledge. The way how I overcome it, is by mingling around with elder people and working people. (Male student from Teikyo University)

The analysis indicates that the second most common response among 36 percent of the respondents to the open-ended question is dealing with the social environment in Japan. The responses to the concerns in environment includes life style, weather, food, cleanliness, waste management system, education system and so on. Some respondents commented that,

I try to avoid all the common acts that are well-practiced in Malaysia but that are considered impolite in Japan, be it intentional or vice versa. Some examples include: adding all kinds of waste without recycling, use of mobile phone in public vehicles and ensure that all parts of toilet are dry after use, if there are splashes of water, it must be wipe out before exiting. (Female student from Hirosaki University) 
I guess the most challenging aspect is to adapt ourselves to the new and different environment here. By the environment I mean to adapt ourselves to the way of living of the Japanese, the way they deal with matters etc. In short word, to adapt ourselves to the distinct culture of the Japanese. (Male student from Tohoku University)

Being a Muslim, the hardest part is of course the difficulty in practicing your religion, especially in terms of regular prayers and restrictions on certain foods. (Male student from Meiji University)

In Malaysia, I only know to throw the rubbish in one dustbin. However, as soon as I reached my dormitory a year ago, I was shocked that at least 5 dustbins were prepared in the dormitory. I was told that I have to differentiate the rubbish into plastic, can, glass, combustible and incombustible. Another thing was that the Japanese are wearing slippers inside the house or dormitory. In Malaysia, we don't wear slippers. (Male student from Hakodate National College of Technology)

I'm adapted with learning system at university. (Male student from University of Toyama)

The third highest category of responses among 30 percent of the respondents concerns the issue of time management. As widely known, Japanese society is quite strict about time which is a national norm of the Japanese. The Japanese place great emphasis on punctuality, the most significant example being the time schedule in the railway system. On this issue, respondents commented,

The one adjustment is my habits of being late when attending a meeting or class. Generally, Japanese do not tolerate tardiness or not being punctual. So I have to wake up early so that I won't be late to class or to meet someone. So I think that is the biggest change in me since I come here. (Male student from Meiji University)

I've turned into someone who does really care about time even a minute. (Female student from Ritsumeikan University)

I try to be punctual like the Japanese. I learn to do things more systematically and to do the things properly with all my might. After I came to Japan, I begin to understand how important a 
plan is. Due to that, I begin to plan my own schedule and finish all the tasks assigned by my lectures on time. (Male student from Hakodate National College of Technology)

\section{Self time management. (Male student from Keio University)}

Meanwhile, about $25 \%$ of respondents highlighted that personal changes become important adaptation aspect when participating in study abroad programmes in Japan which included more tolerance towards different cultures, independence, new way of thinking, and being more friendly and open-minded. Some observations from the respondents include,

I have changed my way of thinking quite radically since I came here. (Male student from Osaka University)

I learned to rely more on myself, be independent and face my own problem personally. (Male student from Meiji University)

I'm willing to explain with others people about my own culture and religion. (Female student from Osaka University)

I become more refine in my actions. I've gain a high level of tolerance to adapt my different beliefs and traditions into the Japanese culture. (Female student from Kitami Institute of Technology)

Become more independent. (Female student from Tohoku University)

I try to become friendly. (Male student from Toyohashi University of Technology)

I used to feel very uneasy when experiencing new thing, but ever since coming here, I am now more open to new things. (Male student from Tokyo Institute of Technology)

I try becoming more approachable towards others because Japanese is quite passive in that. (Male student from Tokai University)

Furthermore, about 18percent of respondents mentioned understanding about host culture and 4 percent emphasized about financial management. Some said,

I try to understand about Japanese attitudes and life style. (Female student from Chuo University)

I am taking class related to Japanese culture and so that I can adapt to the living environment here. (Female student from Akita University) 
Financial management. (Male student from Shobi University)

\section{Discussion and Conclusion}

The purpose of this study was to understanding the impact of study abroad participation from Malaysian students' perspective. The result of this research demonstrates that respondents gained greater personal adaptation, understanding about foreign culture, intercultural communication abilities, openness to diversity and global awareness. In addition, statistical analysis indicates that students had positive correlation between learning outcomes. Clearly, study abroad programmes provide students with first-hand experiences in engaging in international interactions and developing one's own competence in facing global competativeness within a diverse workforce. The researchers would like to empasize that individuals who travel abroad require three basic preparation skills to adapt into a new cultural environment. These are students must be able to improve their intercultural communication skills, willingly accept and understand other cultures.

\section{Improve intercultural communication}

Based on the analysis, most students struggle to deal with language barriers during the learning process in class and when interacting with Japanese students. Kim and Gudykunst state that "we communicate the way we do because we are raised in a particular culture and learn its language, rules and norms". ${ }^{18}$ Intercultural communication relates modifying one's own communication style to that of a new one in terms of behavioural patterns, languages, values and norms. ${ }^{19}$ Individuals must understand differences in communication between cultures when interacting in a foreign environment.

\section{Willingness to accept other culture}

Foreign students mostly are faced with an unfamiliar life style culture and environment when they embark on study programmes abroad. The finding explains that individuals become successful in adapting when they are willing to accept other cultures. This means that they have a positive perception of the host, are able to adjustment psychologically in a new environment, are open-minded and want to establish interpersonal relationships with the locals.

\section{Understanding about different culture}

Each culture has its uniqueness. Through intercultural interactions, individuals must be able to understand different cultures as well as develop mutual understanding with the host country population. Most of the respondents highlighted that study abroad programme in Japan gave

\footnotetext{
${ }^{18}$ William B. Gudykunst, Kim Young Yun, "Communicating with strangers: An approach to intercultural communication," in Bridges Not Walls, 6th ed., ed. John Stewart (New York: McGraw-Hill, 1995), p 430.

19 Milton J. Bennet, "Intercultural communication: A current perspective," in Basic concepts of intercultural communication: Selected readings, ed. Bennet, M.J. (Yarmouth, ME: Intercultural Press, 1998).
} 
them opportunities to learn and understand the attitude of Japanese people which in the long run contributed to enhancing their competence to get along with people of different cultures. Meanwhile, in a global context, students who study abroad can be considered as "cultural ambassadors" to promote peace and prosperity in the $21^{\text {st }}$ century. This allows for heightened intercultural understanding of the outside world. Finally, the study concludes that study abroad programmes are great assets in promoting understanding between Malaysia and Japan through individual interactions and relationships.

\section{Suggestions for Future Research}

Student mobility in various modes of outbound programmes, whether short-term or long-term needs more research in terms of the impact of studying abroad on students. Future research should focus on a more qualitative method on investigating the 'culture shock' experienced by students and the challenges of adaptation and psychology of living abroad. Further, research should also compare the impact of studying between Asian and western cultured environments. Similarly, research should be done assessing the impact of learning outcomes among students who study locally but have dealings with foreign students in a multicultural environment is also needed. Finally, further research should also take into account the differing demographic sample and challenges faced by administrators in sending students abroad to study.

\section{References}

Anderson, L. E. 1994. A new look at an old construct: Cross-cultural adaptation. International Journal of Intercultural Relations 18, no. 3: 293-328.

Anderson, P. H., L. Lawton, R. J. Rexeisen, and A. C. Hubbard. 2006. Short-term study abroad and intercultural sensitivity: A pilot study. International Journal of Intercultural Relations 30, no. 4: 457-469.

Armfield, P. A.. An examination of the relationship between students' interaction with host nationals while on study abroad and their development of intercultural sensitivity. $\mathrm{PhD}$ diss., 2004.

Bayles, P. P. Assessing the intercultural sensitivity of elementary teachers in bilingual schools in a Texas school district. PhD diss., University of Minnesota, 2009.

Bennett, M. J. 1986. A developmental approach to training for intercultural sensitivity. International journal of intercultural relations 10, no. 2: 179-196.

Bennett, M. J. 1998. Intercultural communication: A current perspective. Basic concepts of intercultural communication: Selected readings, ed. Bennet, M. J. 1-34. Yarmouth, ME: Intercultural Press.

Berkeley International Office. 2010. Cultural adjustment. Accessed March 122013. http://internationaloffice.berkeley.edu/cultural_adjustment

Bhawuk, D. P., and R. Brislin. 1992. The measurement of intercultural sensitivity using the concepts of individualism and collectivism. International Journal of Intercultural Relations 16, no.4: 413-436. 
Bond, L., S. Koont, and S. Stephenson. 2005. The Power of Being There: Study Abroad in Cuba and the Promotion of a" Culture of Peace". Frontiers: The Interdisciplinary Journal of Study Abroad 11: 99-120.

Center for Global and Intercultural Study. 2011. Global perspective. Accessed June 52012. http://www.lsa.umich.edu/cgis/Research/preandpost.html

Chen, G-M., and W. J. Starosta. 1996. Intercultural communication competence: A synthesis. Communication yearbook 19: 353-384.

Cross, S. E. 1995. Self-construals, coping, and stress in cross-cultural adaptation. Journal of Cross-Cultural Psychology 26, no.6: 673-697.

Douglas, C., and C. G. Jones-Rikkers. 2001. Study abroad programs and American student worldmindedness: An empirical analysis. Journal of Teaching in International Business 13, no. 1: 55-66.

Dwyer, M. M. 2004. More Is Better: The Impact of Study Abroad Program Duration. Frontiers: The Interdisciplinary Journal of Study Abroad 10: 151-163.

Engle, L., and J. Engle. 2004. Assessing Language Acquisition and Intercultural Sensitivity Development in Relation to Study Abroad Program Design. Frontiers: The Interdisciplinary Journal of Study Abroad 10: 219-236.

Fuller, T. L. 2007. Study abroad experiences and intercultural sensitivity among graduate theological students: A preliminary and exploratory investigation. Christian higher education 6, no. 4: 321-332.

Golay, P. A. The effects of study abroad on the development of global-mindedness among students enrolled in international programs at Florida State University. PhD diss., The Florida State University, 2006.

Goldstein, D. L., and D. H. Smith. 1999. The analysis of the effects of experiential training on Sojourners cross-cultural adaptability. International Journal of Intercultural Relations 23, no. 1: 157-173.

Gudykunst, W., and Kim, Y. Y. 1996. Communicating with strangers: An approach to intercultural communication. In Bridges Not Walls, $6^{\text {th }}$ ed., ed. John Stewart, 42942.New York: McGraw-Hill.

Hansen, R. A. 2010. Impact of study abroad on ethnocultural empathy and globalmindedness. PhD diss., Ball State University, 2010.

Herrera, S. W. 2008. Effectiveness of study abroad in developing global competence and global consciousness: Essential outcomes for internationalizing the curriculum. PhD diss., University of Florida, 2008.

Hunter, W. D. Knowledge, skills, attitudes, and experiences necessary to become globally competent. PhD diss., Lehigh University, 2004.

lee Olson, C., and K. R. Kroeger. 2001. Global competency and intercultural sensitivity." Journal of Studies in International Education 5, no. 2: 116-137.

Jackson, J. 2008. Globalization, internationalization, and short-term stays abroad. International Journal of Intercultural Relations 32, no. 4: 349-358.

Kehl, K., and J. Morris. 2007. Differences in global-mindedness between short-term and semester-long study abroad participants at selected private universities. Frontiers: The Interdisciplinary Journal of Study Abroad 15: 67-79.

Kim, Y. Y. 2000. Becoming intercultural: An integrative theory of communication and crosscultural adaptation. Thousand Oaks: Sage Publications. 
Kim, Y. Y. 2002. Adapting to an unfamiliar culture: An interdisciplinary overview. In Handbook of International and Intercultural Communication, 2nd ed., ed. Gudykunst, W. B., and B. Mody, 259-74. Thousand Oaks: Sage Publications.

Kuo, B,C., and G. Roysircar. 2006. An exploratory study of cross-cultural adaptation of adolescent Taiwanese unaccompanied sojourners in Canada. International Journal of Intercultural Relations 30, no. 2: 159-183.

Lohmann, J. R., H. A. Rollins, and J. Joseph Hoey. 2006. Defining, developing and assessing global competence in engineers. European journal of engineering education 31, no. 01: 119-131.

Matsumoto, D., J. LeRoux, C. Ratzlaff, H. Tatani, H. Uchida, C. Kim, and S. Araki. 2001. Development and validation of a measure of intercultural adjustment potential in Japanese sojourners: The Intercultural Adjustment Potential Scale (ICAPS). International Journal of Intercultural Relations 25, no. 5: 483-510.

McCabe, L.T. 1994. The development of a global perspective during participation in semester at sea: A comparative global education program. Educational Review 46, no. 3: 275-286.

Medina-Lopez-Portillo, A. 2004. Intercultural Learning Assessment: The Link between Program Duration and the Development of Intercultural Sensitivity. Frontiers: The Interdisciplinary Journal of Study Abroad 10: 179-199.

Merrill, K. C., D. C. Braskamp, and L. A. Braskamp. 2012. Assessing Individuals' Global Perspective. Journal of College Student Development 53, no. 2: 356-360.

Pitts, M. J. 2009. Identity and the role of expectations, stress, and talk in short-term student sojourner adjustment: An application of the integrative theory of communication and cross-cultural adaptation. International Journal of Intercultural Relations 33, no. 6: 450462.

Robertson, R. 1992. Globalization: social theory and global culture. London: Sage.

Ruben, B. D., and D. J. Kealey. 1979. Behavioral assessment of communication competency and the prediction of cross-cultural adaptation. International Journal of Intercultural Relations 3, no. 1: 15-47.

Sampson, D. L., and H. P. Smith. 1957. A scale to measure world-minded attitudes. The Journal of Social Psychology 45, no. 1: 99-106.

Searle, W., and C. Ward. 1990. The prediction of psychological and sociocultural adjustment during cross-cultural transitions. International Journal of Intercultural Relations 14, no. 4: 449-464.

Steger, M. 2010. Globalization. New York:Sterling Publishing Company, Inc.

Straffon, D. A. 2003. Assessing the intercultural sensitivity of high school students attending an international school. International Journal of Intercultural Relations 27, no. 4: 487-501.

Ting-Toomey, S. 2012. Communicating across cultures. London: Guilford Press.

Tischler, H. L. 2010. Introduction to Sociology. Belmont, CA: Cengage Learning.

Van Der Zee, K. I., and J. P. Van Oudenhoven. 2000. The Multicultural Personality

Questionnaire: A multidimensional instrument of multicultural effectiveness. European journal of personality 14, no. 4: 291-309.

Ward, C., and A. Kennedy. 1999. The measurement of sociocultural adaptation. International journal of intercultural relations 23, no. 4: 659-677. 
Ward, C., and A. Kennedy. 1993. Psychological and socio-cultural adjustment during crosscultural transitions: A comparison of secondary students overseas and at home. International Journal of Psychology 28, no. 2: 129-147.

Ward, C., and A. Kennedy. 1994. Acculturation strategies, psychological adjustment, and sociocultural competence during cross-cultural transitions. International Journal of Intercultural Relations 18, no. 3: 329-343.

Ward, C., Y. Okura, A. Kennedy, and T. Kojima. 1998. The U-curve on trial: A longitudinal study of psychological and sociocultural adjustment during cross-cultural transition. International Journal of Intercultural Relations 22, no. 3: 277-291.

Williams, T. R.. 2005. Exploring the impact of study abroad on students' intercultural communication skills: Adaptability and sensitivity. Journal of Studies in International Education 9, no. 4: 356-371.

Winkelman, M.1994. Cultural shock and adaptation. Journal of Counseling \& Development 73, no. 2: 121-126.

Wortman, T. I. Psychosocial effects of studying abroad: Openness to diversity. PhD diss., The Pennsylvania State University, 2002.

Yamazaki, Y., and D. C. Kayes. 2004. An experiential approach to cross-cultural learning: A review and integration of competencies for successful expatriate adaptation. Academy of Management Learning \& Education 3, no. 4: 362-379.

Yu, HungChih. An Examination of the Effects of Participation in a College Study Abroad Program. ProQuest, 2008.

Zhai, L., and S. D. Scheer. 2002. Influence of international study abroad programs on agricultural college students. Journal of International Agricultural and Extension Education 9, no. 3: 23-29. 